\title{
Evaluation of analgesic activity and toxicity of alkaloids in Myristica fragrans seeds in mice
}

\author{
A Al-Shammary Hayfaa' \\ AA Malik Al-Saadi Sahar ${ }^{2}$ \\ M Al-Saeidy Awatif ${ }^{3}$ \\ 'College of Science, Department of \\ Medical Analysis, Thi-Qar University, \\ Thi-Qar, Iraq; ${ }^{2}$ College of Science, \\ Biology Department, University of \\ Basrah, Basrah, Iraq; ${ }^{3}$ College of \\ Science, Biology Department, \\ Thi-Qar University, Thi-Qar, Iraq
}

This article was published in the following Dove Press journal: Journal of Pain Research

I August 2013

Number of times this article has been viewed
Aim: To examine the analgesic effect of alkaloids in Myristica fragrans seed in a mouse model of acetic acid-induced visceral pain.

Methods: Alkaloids were extracted from ground nutmeg seed kernels with $10 \%$ acetic acid in $95 \%$ ethyl alcohol. Visceral pain was induced in male and female BALB/c mice by intraperitoneal injection of $0.6 \%$ acetic acid. Analgesic effect of alkaloids ( 0.5 gram or 1 gram per kilogram $[\mathrm{g} / \mathrm{kg}]$, by mouth) was assessed by evaluating writhing response. Acute toxicity was tested in response to $2,3,4,5$, or $6 \mathrm{~g} / \mathrm{kg}$ of alkaloid extract; the median lethal dose $\left(\mathrm{LD}_{50}\right)$ was determined by probit analysis.

Results: Alkaloid extract at a dose of $1 \mathrm{~g} / \mathrm{kg}$ significantly reduced the number of writhing responses in female, but not male mice; $0.5 \mathrm{~g} / \mathrm{kg}$ of alkaloid extract had no effect in either sex. The $\mathrm{LD}_{50}$ was $5.1 \mathrm{~g} / \mathrm{kg}$. Signs of abnormal behavior, including hypoactivity, unstable gait, and dizziness were seen in animals given a dose of $4 \mathrm{~g} / \mathrm{kg}$ or higher; abnormal behavior lasted for several hours after administration of the alkaloids.

Conclusion: According to the classification of Loomis and Hayes, M. fragrans seed alkaloids have analgesic activity and are slightly toxic.

Keywords: analgesic, mice, $\mathrm{LD}_{50}$, acetic acid, visceral pain, nutmeg

\section{Introduction}

Myristica fragrans Houtt (nutmeg) is an aromatic evergreen tree of the plant family Myristicaceae. ${ }^{1}$ Nutmeg, the actual seed of the tree, is important in folk medicine, where it is used to treat colds, fever, catarrh, general respiratory ailments, and skin diseases like scabies. It is also used as an appetite stimulant, carminative, antiemetic, and abortifacient. ${ }^{2,3}$

In controlled laboratory studies, M. fragrans has been shown to possess insulin-like, ${ }^{4}$ insecticidal, ${ }^{5-8}$ antibacterial, ${ }^{9-12}$ and antioxidant activities. ${ }^{13}$ However, prolonged use of nutmeg can cause degenerative changes in the kidney, spleen, liver, heart, medial geniculate body, and superior colliculus. ${ }^{13-16}$

Alkaloids are any of a class of naturally occurring, organic nitrogen-containing bases. Traditionally isolated from plants, alkaloids have been increasingly found in animals, insects, marine invertebrates, and microorganisms. ${ }^{17-19}$ Plant-derived alkaloids elicit many biological effects, including analgesia. Previous studies have demonstrated that an acetone-soluble substance within the n-hexane extract of $M$. fragrans exerts analgesic activity; ${ }^{20,21}$ however, the identity of the active constituents responsible for the analgesic activity remains unknown. Thus, the present study was designed to study the analgesic effect of alkaloids extracted from $M$. fragrans seeds in mice subjected
Correspondence: A Al-Shammary Hayfaa College of Science, Department of Medical Analysis, Thi-Qar University, Al-mtanzah Street, Nassriya, Thi-Qar, Iraq

Email hayfaashamer@yahoo.com 
to acetic acid-induced visceral pain and to assess the acute toxicity of these alkaloids.

\section{Materials and methods Plant materials}

Dried M. fragrans seeds were collected from Iraqi markets in Thi-Qar City, Iraq and authenticated as M. fragrans seeds by AA Malik Al-Saadi Sahar. Only the seed kernels (nutmeg) were used in this study.

\section{Detection of alkaloids}

Seed kernels were ground to a fine powder. Fifty $\mathrm{mL}$ of $4 \%$ $\mathrm{HCl}$ was added to 10 grams of nutmeg powder, heated to a boil, cooled, and filtered. Three drops each of Mayer's reagent/ picric acid/Dragendorff's reagent were added to $0.5 \mathrm{~mL}$ of filtrate. The presence of alkaloid was indicated as a white precipitate (Mayer's reagent), a yellow precipitate (picric acid), or an orange precipitate (Dragendorff's reagent). ${ }^{22}$

\section{Alkaloid extraction}

Crude alkaloid compounds were extracted according to the modified method of Harborne. ${ }^{22}$ Crushed seed kernels (20 grams) were suspended in $200 \mathrm{~mL}$ of hexane, and lipid soluble impurities were removed by continuous extraction using a Quickfit ${ }^{\circledR}$ Soxhlet apparatus (Sigma-Aldrich, St Louis, MO, USA). Kernels were dried under laboratory conditions and subjected to an extraction process with $200 \mathrm{~mL}$ of $10 \%$ acetic acid in $95 \%$ ethyl alcohol for 24 hours in the Soxhlet apparatus. The extract was filtered through No 1 Whatman filter paper (BDH Pharmaceuticals, London, UK) and concentrated by a rotary evaporator (Bibby Scientific Ltd, Staffordshire, UK) at $45^{\circ} \mathrm{C}$ to $20 \mathrm{~mL}$. The $\mathrm{pH}$ was adjusted to 9 by adding concentrated ammonium hydroxide solution, and the solution was partitioned three times with $50 \mathrm{~mL}$ of chloroform in a separation funnel, which was shaken vigorously and left to stand each time. The extract separated into two layers. The lower (chloroform) layer contained the alkaloids, which was confirmed with Mayer's reagent, picric acid, or Dragendorff's reagent. The chloroform layer was concentrated using a rotary evaporator and left to dry under laboratory conditions. Dried alkaloids were stored in a clean, dark vial at $4^{\circ} \mathrm{C}$.

\section{Experimental animals}

Two-month-old BALB/c mice of both sexes, weighing 20-25 grams, were obtained from the animal house, College of Science, Thi-Qar University. The animals were housed in a vivarium maintained under standard hygienic conditions at $20^{\circ} \mathrm{C} \pm 2^{\circ} \mathrm{C}$ with a 12 -hour day/night cycle and access to food and water ad libitum. Animals were treated in accordance with the Ethical Guidelines for the Investigation of Experimental Pain in Conscious Animals issued by the International Association for the Study of Pain, and were approved by the local animal care ethics committee. ${ }^{23}$

\section{Acute toxicity study}

Male and female mice were divided into six groups of twelve mice each (six males and six females). Animals were matched for weight and size and allowed to acclimate for 3 days. Groups were given vehicle or 2, 3, 4, 5, or $6 \mathrm{~g} / \mathrm{kg}$ of nutmeg alkaloids suspended in $0.4 \mathrm{~mL}$ of $70 \%$ ethanol:distilled water (1:3 by volume) by oral gavage. Animals were observed for 72 hours for behavioral changes or mortality. The median lethal dose $\left(\mathrm{LD}_{50}\right)$ was determined by probit analysis.

\section{Analgesic activity in the acetic acid-induced writhing model}

Mice were randomly divided into four groups of twelve animals each (six males and six females) and set to receive: (1) vehicle $(0.4 \mathrm{~mL} 70 \%$ ethanol:distilled water [1:3 by volume]) delivered orally; (2) diclofenac sodium (20 mg/kg) delivered by intraperitoneal injection; (3) M. fragrans seed alkaloids $(0.5 \mathrm{~g} / \mathrm{kg})$ delivered orally in $0.4 \mathrm{~mL}$ of vehicle; or (4) M. fragrans seed alkaloids $(1 \mathrm{~g} / \mathrm{kg})$ delivered orally in $0.4 \mathrm{~mL}$ of vehicle.

Animals were placed separately into a cage and allowed to acclimate for at least 10 minutes. Mice were given vehicle,

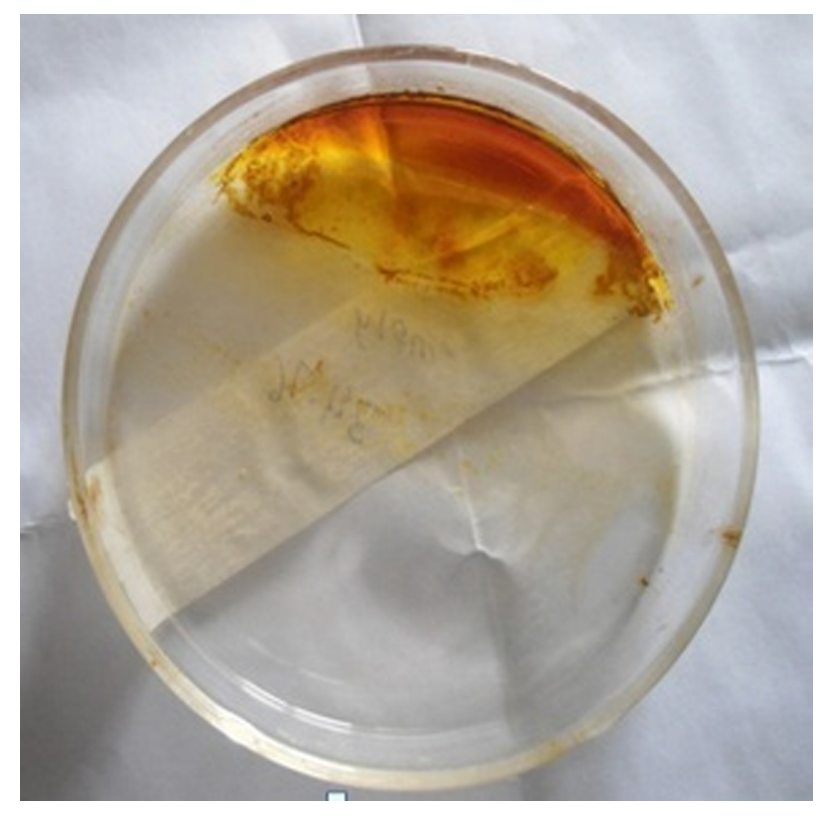

Figure I Alkaloids extracted from Myristica fragrans seeds. 
Table I Acute toxicity of Myristica fragrans alkaloids

\begin{tabular}{|c|c|c|c|c|c|c|c|c|c|c|}
\hline \multirow{3}{*}{$\begin{array}{l}\text { Dose } \\
\text { g/kg }\end{array}$} & \multicolumn{4}{|l|}{ Male } & \multicolumn{4}{|l|}{ Female } & \multirow{3}{*}{$\begin{array}{l}\text { Total } \\
\text { number of } \\
\text { dead animals }\end{array}$} & \multirow{3}{*}{$\begin{array}{l}\text { Mortality } \\
\%\end{array}$} \\
\hline & \multirow{2}{*}{$\begin{array}{l}\text { Total } \\
\text { number }\end{array}$} & \multicolumn{3}{|c|}{ Dead animals } & \multirow{2}{*}{$\begin{array}{l}\text { Total } \\
\text { number }\end{array}$} & \multicolumn{3}{|c|}{ Dead animals } & & \\
\hline & & 24 hours & 48 hours & 72 hours & & 24 hours & 48 hours & 72 hours & & \\
\hline 2 & 6 & 0 & 0 & 0 & 6 & 0 & 0 & 0 & 0 & 0 \\
\hline 3 & 6 & 0 & 0 & 0 & 6 & 0 & 0 & 0 & 0 & 0 \\
\hline 4 & 6 & I & 0 & 0 & 6 & 2 & 0 & 0 & 3 & 25 \\
\hline 5 & 6 & 3 & 0 & 0 & 6 & 2 & 0 & 0 & 5 & 41.6 \\
\hline 6 & 6 & 3 & 0 & 0 & 6 & 6 & 0 & 0 & 9 & 75 \\
\hline
\end{tabular}

diclofenac, or alkaloid suspensions 1 hour prior to induction of visceral pain. Visceral pain was induced by intraperitoneal injection of a $0.6 \%$ volume per volume $(10 \mathrm{~mL} / \mathrm{kg})$ glacial acetic acid solution in normal saline. Animals were returned to their cages and observed for writhing behavior, indicated by stretching of the abdomen with simultaneous stretching of at least one hind limb. ${ }^{24}$ The number of writhing responses was counted for 15 minutes, starting directly after the acid injection.

\section{Statistical analysis}

Data are expressed as mean \pm standard error of the mean and were analyzed by two-way analysis of variance. Differences among means were considered significant at $P<0.01$ using the Fisher's Least Significant Difference. Analyses were performed using the Statistical Product and Service Solutions, 2006 (IBM Corporation, Armonk, NY, USA).

\section{Results}

\section{Detection of alkaloids}

The appearance of white, yellow, or orange precipitate using Mayer's reagent, picric acid, or Dragendorff's reagent, respectively, revealed the presence of alkaloids. Figure 1 is a representative picture, showing alkaloids extracted from nutmeg as a brown sticky material.

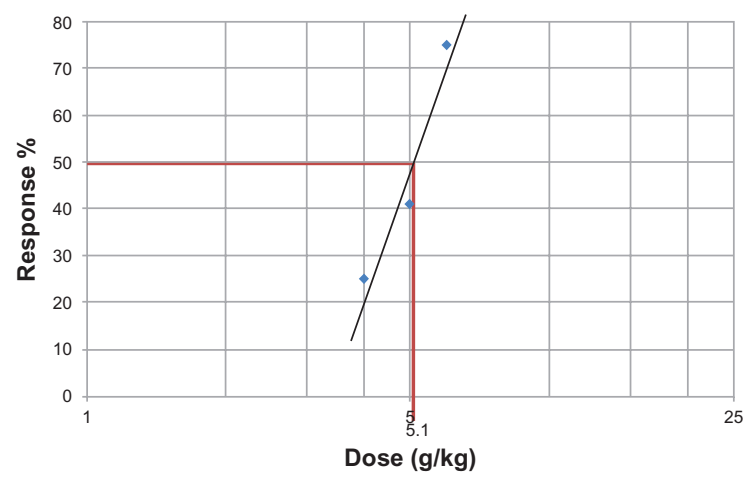

Figure 2 Probit plot of deaths caused by acute treatment with Myristica fragrans alkaloids.

\section{Acute toxicity study}

The number of deaths resulting from administration of M. fragrans crude alkaloids is given in Table $1 ; \mathrm{LD}_{50}$ was $5.1 \mathrm{~g} / \mathrm{kg}$ (Figure 2). Animals given a dose of $4 \mathrm{~g} / \mathrm{kg}$ or greater exhibited abnormal behavior, including hypoactivity, unstable gait, or dizziness lasting for several hours, doses of $3 \mathrm{~g} / \mathrm{kg}$ or less did not elicit any abnormal behavior.

\section{Analgesic activity of the alkaloids}

The analgesic effect of nutmeg crude alkaloids in the acetic acid-induced writhing model is shown in Table 2. The number of writhing responses was significantly reduced in female, but not in male mice treated with alkaloids at a dose $1 \mathrm{~g} / \mathrm{kg}$ of alkaloids; $0.5 \mathrm{~g} / \mathrm{kg}$ had no effect in either sex. Diclofenac caused comparable decreases in the number of writhing responses in male and female mice; the effect of diclofenac was significantly greater than that of nutmeg alkaloids.

\section{Discussion}

\section{Acute toxicity study}

In this study, the $\mathrm{LD}_{50}$ of alkaloids extracted from M. fragrans seeds was calculated to be $5.1 \mathrm{~g} / \mathrm{kg}$. According to classifications put forth by Pascoe ${ }^{25}$ and by Loomis and Hayes, ${ }^{26}$ this corresponds to ratings of slightly toxic and practically nontoxic, respectively. Our results agree with those from previous studies examining the effects of other extracts derived

Table 2 Number of writhing responses induced by acetic acid

\begin{tabular}{llll}
\hline Treatment & Female & Male & $\begin{array}{l}\text { Mean } \\
\text { treatment }\end{array}$ \\
\hline Control & $22 \pm 3^{\mathrm{a}, \mathrm{b}}$ & $22 \pm 2^{\mathrm{a}, \mathrm{b}}$ & $22 \pm 2^{\mathrm{a}}$ \\
$0.5 \mathrm{~g} / \mathrm{kg}$ & $23 \pm 3^{\mathrm{a}}$ & $21 \pm 3^{\mathrm{b}}$ & $22 \pm 2^{\mathrm{a}}$ \\
$\mathrm{I} \mathrm{g/kg}$ & $17 \pm 4^{\mathrm{c}}$ & $21 \pm 4^{\mathrm{b}}$ & $19 \pm 3^{\mathrm{b}}$ \\
Diclofenac & $4 \pm \mathrm{I}^{\mathrm{d}}$ & $4 \pm \mathrm{I}^{\mathrm{d}}$ & $4 \pm \mathrm{I}^{\mathrm{c}}$ \\
Mean & $17 \pm 2$ & $17 \pm 2$ & \\
LSD & Treatment $=2.53$ & Interaction $=1.49$ & Sex NS \\
\hline
\end{tabular}

Note: Values represent mean \pm SEM. Values with nonidentical superscripted letters $(a-d)$ are considered significantly different $(P<0.01)$.

Abbreviations: SEM, standard error of the mean; LSD, least significant difference; NS, non significant. 
from $M$. fragrans. In those studies, the acetone-soluble component of the n-hexane extract ${ }^{21}$ and a $50 \%$ ethanolic extract ${ }^{27}$ caused no deaths and had no effect on behavior up to doses 3 and $4 \mathrm{~g} / \mathrm{kg}$, respectively.

\section{Analgesic activity}

The acetic acid-induced writhing model is used to evaluate the effect of analgesics such as nonsteroidal anti-inflammatory drugs on visceral pain. ${ }^{28,29}$ We found that alkaloids extracted from $M$. fragrans seeds caused a modest, but significant, reduction in writhing behavior in female, but not male mice.

Acetic acid causes pain by releasing endogenous mediators that stimulate nociceptive neurons. These include cytokines, such as interleukin-1 $\beta$ and interleukin- 8 released by resident peritoneal macrophage and mast cells, and prostaglandins and lipooxygenase products released into the peritoneum..$^{29-31}$ Nonsteroidal anti-inflammatory drugs induce analgesia by inhibiting prostaglandin synthesis via the cyclooxygenase pathway. ${ }^{32}$ Chemical substance extracts from Myristicaceae plants have been shown to inhibit phospholipase $A_{2}$, thus lowering the availability of arachidonic acid precursor for prostaglandin synthesis. ${ }^{33}$ Other investigators have postulated that the antinociceptive activity of plant extracts may be due to inhibition of interleukin-1 $\beta$ and interleukin- 8 release by resident peritoneal cells or to suppression of prostaglandins and bradykinin; ${ }^{32,34,35}$ however, direct evidence for these actions is lacking.

There is some variability in the literature regarding the criteria applied to evaluate writhing behavior. Some investigators have divided these into complete (or full) and half responses; two half responses are considered to be one complete response. Others have evaluated the response similar to the method used in the present study. ${ }^{24,36}$

We conclude that alkaloids derived from $M$. fragrans seeds possess analgesic activity. However, further study is warranted to identify the active constituent.

\section{Disclosure}

The authors report no conflicts of interest in this work.

\section{References}

1. Joseph J. The nutmeg: its botany, agronomy, production, composition, and uses. Journal of Plantation Crops. 1980;8(2):61-72.

2. Bamidele O, AkinnugaAM, Alagbonsi IA, Ojo OA, Olorunfemi JO, Akuyoma MA. Effects of ethanolic extract of Myristica fragrans Houtt. (nutmeg) on some heamatological indices in albino rats. International Journal of Medicine and Medical Sciences. 2011;3(6):215-218.

3. Nadkarni K. Myristica Fragrans. In: Indian Materia (3rd ed.), Bombay: Bombay Popular Prakashan; 1988.
4. Broadhurst CL, Polansky MM, Anderson RA. Insulin-like biological activity of culinary and medicinal plant aqueous extracts in vitro. JAgric Food Chem. 2000;48(3):849-852.

5. Adedire CO. Use of nutmeg Myristica fragrans (Houtt.) powder and oil for the control of cowpea storage bruchid, Callosobruchusmacul atusFabricius. ZeitschriftfürPflanzenkrankheiten und Pflanzenschutz. 2002;109(2):193-199.

6. Chaubey MK. Fumigant toxicity of essential oils from some common spices against pulse beetle Callosobruchuschinensis (Coleoptera: Bruchidae). JOleo Sci. 2008;57(3):171-179.

7. Jung WC, Jang YS, Hieu TT, Lee CK, Ahn YJ. Toxicity of Myristica fagrans seed compounds against Blattellagermanica (Dictyoptera: Blattellidae). J Med Entomol. 2007;44(3):524-529.

8. Park IK, Kim JN, Lee YS, Lee SG, Ahn YS, Shin SC. Toxicity of plant essential oils and their components against Lycoriellaingenua (Diptera: Sciaridae). J Econ Entomol. 2008;101(1):139-144.

9. Cho JY, Choi GJ, Son SW, et al. Isolation and antifungal activity of lignans from Myristica fragrans against various plant pathogenic fungi. Pest Manag Sci. 2007;63(9):935-940.

10. Indu MN, Hatha AAM, Abirosh C, Harsha U, Vivekanandan G. Antimicrobial activity of some of the south-Indian spices against serotypes of Escherichia coli, Salmonella, Listeria Monocytogenes, and Aeromonas Hydrophila. Brazilian Journal of Microbiology. 2006;37(2): 153-158.

11. Narasimhan B, Dhake AS. Antibacterial principles from Myristicafragrans seeds. J Med Food. 2006;9(3):395-399.

12. TakikawaA, Abe K, Yamamoto M, et al. Antimicrobial activity of nutmeg against Escherichia coli O157. J BiosciBioeng. 2002;94(4):315-320.

13. Olaleye MT, Akinmoladun CA, Akindahunsi AA. Antioxidant properties of Myristica fragrans (Houtt) and its effect on selected organs of albino rats. African Journal of Biotechnology. 2006;5(15):1274-1278.

14. Adjene JO, Nwose EU. Histological effects of long term consumption of nutmeg on the medial geniculate body of adult Wistar rats. $N \mathrm{Am} \mathrm{J}$ Med Sci. 2010;2(3):134-137.

15. Adjene JO. Histological effects of chronic consumption of nutmeg on the superior colliculus of adult Wistar rats. International Journal of Biomedical and Health Sciences. 2010;6(1):51-55.

16. Eweka AO, Eweka A. Histological effects of oral administration of nutmeg on the kidneys of adult Wistar rats. NAm J Med Sci. 2010;2(4): 189-192.

17. Gleason FK, Cholett R. Plant Biochemistry. Sudbury, Mass: Jones \& Bartlett Learning LLC; 2012:1-22.

18. Grycová L, Dostál J, Marek R. Quaternary protoberberine alkaloids. Phytochemistry. 2007;68(2):150-175.

19. Robert MF, Wink M, editors. Introduction. In: Robert MF, Wink M, editors. Alkaloids: Biochemistry, and Medical Application Language of Science. Springer 1998:1-6.

20. Grover JK, Khandkar S, Vats V, DhunnooY, Das D. Pharmacological studies on Myristica fragrans - antidiarrhoeal, hypnotic, analgesic and hemodynamic (blood pressure) parameters. Methods Find Exp Clin Pharmacol. 2002;24(10):675-680.

21. Sonavane G, SarveiyaV, Kasture V, Kasture SB. Behavioural actions of Myristica fragrans seeds. Indian Journal of Pharmacology. 2001;33(6): $417-424$.

22. Harborne JB. Phytochemical Methods. 2nd ed. New York: Chapman and Hall; 1984.

23. Zimmermann M. Ethical guidelines for investigations of experimental pain in conscious animals. Pain. 1983;16(2):109-110.

24. Sharma AK, Agarwal V, Kumar R, Balasubramaniam A, Mishra A, Gupta R. Pharmacological studies on seeds of Alangiumsalvifolium Linn. Acta Pol Pharm. 2011;68(6):897-904.

25. Pascoe D. Toxicology. Edward Arnold Limited. London; 1983:1-60.

26. Loomis TA, Hayes AW. Loomis's Essentials of Toxicology. 4th ed. California: Academic Press; 1996.

27. Tajuddin A, Ahmad S, Latif A, Qasmi IA, Amin KM. An experimental study of sexual function improving effect of Myristica fragrans Houtt. (Nutmeg). BMC Complementary and Alternative Medicine. 2005;5:16. 
28. Ghosh AK, Banerje M, Mandal TK, Mishra A, Bhowmik MK. A study on analgesic efficacy and adverse effects of aloe vera in Wistarrats. Pharmacology Online. 2011;1:1098-1108.

29. PrabhuV, Nalini G, ChidambaranathanN, Sudarshan S. Evaluation of anti inflammatory and analgesic activity of Tridaxprocumbens Linn against formalin, acetic acid and CFA induced pain models. International Journal of Pharmacy and Pharmaceutical Sciences. 2011;3(2):126-130.

30. Collier HO, Dinneen LC, Johnson CA, Schneider C. The abdominal constriction response and its suppression by analgesic drugs in the mouse. Br J PharmacolChemother. 1968;32(2):295-310.

31. Ribeiro RA, Vale ML, Thomazzi SM, et al. Involvement of resident macrophages and mast cells in the writhing nociceptive response induced by zymosan and acetic acid in mice. Eur J Pharmacol. 2000;387(1): 111-118.
32. Vane J. The evolution of non-steroidal anti-inflammatory drugs and their mechanisms of action. Drugs. 1987;33(Suppl 1):18-27.

33. SarkarA. Herbal Toxicology. New Delhi: Discovery Publishing House Private Limited; 2009.

34. Mukherjee A, ChalihaM, Das S. Study of analgesic activity of ethanol extracts of Phlogacanthusthyrsiflorus on experimental animal models. Bangladesh Journal of Pharmacology. 2009;4(2):147-149.

35. Jamaluddin ATM, Qais N, Ali MA, Howlader MA, Shams-Ud-Doha KM, Sarker AA. Analgesic activity of extracts of whole plants of Amaranthusspinosus Linn. International Journal of Drug Development and Research. 2011;3(4):189-193.

36. Zulfiker AHM, Rahman MM, Hossain MK, Hamid K, Mazumder MEH, Rana MS. In vivo analgesic activity of ethanolic extract of two medicinal plants - Scopariadulcis L and Ficusracemosa Linn. Biology and Medicine. 2010;2(2):42-48.
Journal of Pain Research

\section{Publish your work in this journal}

The Journal of Pain Research is an international, peer-reviewed, open access, online journal that welcomes laboratory and clinical findings in the fields of pain research and the prevention and management of pain. Original research, reviews, symposium reports, hypothesis formation and commentaries are all considered for publication.

\section{Dovepress}

The manuscript management system is completely online and includes a very quick and fair peer-review system, which is all easy to use. Visit http://www.dovepress.com/testimonials.php to read real quotes from published authors.

\footnotetext{
Submit your manuscript here: http://www.dovepress.com/journal-of-pain-research-journal
} 